\title{
CYTOKINES AND INTRATHECAL IgG SYNTHESIS IN MULTIPLE SCLEROSIS PATIENTS DURING CLINICAL REMISSION
}

\author{
Carlos Otávio Brandão', Heloísa Helena Ruocco², \\ Alessandro dos Santos Farias', Celina Oliveira', \\ Dannie Eiko Maeda Hallal-Longo', Sandra Regina Mirandola', \\ Elaine Conceição Oliveira', Fernando Cendes², \\ Benito Pereira Damasceno ${ }^{2}$, Leonilda Maria Barbosa Santos ${ }^{1}$
}

\begin{abstract}
Cytokines and intrathecal IgG synthesis were determined in the cerebrospinal fluid (CSF) and sera to evaluate inflammatory activity in multiple sclerosis (MS) patients during clinical remission. Although the disease was stable, there had been a significant increase of proinflammatorycytokines such as TNF $\alpha$ and IFN $\gamma$ in the CSF and serum, with no significant changes of IL12 and IL10 production. The changes in the cytokine production patterns were associated with an increase of leukocytes in the CSF, as well as the presence of oligoclonal bands suggesting intrathecal lgG synthesis. These results suggest that even when the disease is clinically silent, one can observe inflammatory activity in these MS patients.
\end{abstract}

KEY WORDS: multiple sclerosis; cerebrospinal fluid; cytokines; intrathecal lgG synthesis.

\begin{abstract}
Citocinas e síntese intratecal de IgG em pacientes com esclerose múltipla durante remissão clínica
RESUMO - Os níveis de citocinas e síntese intratecal de lgG foram dosados no líquido cefalorraquidiano (LCR) e soro, com o objetivo de avaliar a atividade inflamatória em pacientes com esclerose múltipla durante remissão clínica. Foram detectados níveis elevados de citocinas pró-inflamatórias (TNF $\alpha$ e IFN $\gamma$ ) no LCR e soro, sem alterações significativas na produção de IL12 e IL10. O perfil de produção das citocinas pró-inflamatórias estava associado ao aumento de leucócitos no LCR, assim como a presença de bandas oligoclonais IgG sugerindo síntese intratecal de lgG. Estes resultados sugerem que mesmo quando a doença está clinicamente silenciosa, a atividade inflamatória está presente nestes pacientes.
\end{abstract}

PALAVRAS-CHAVE: esclerose múltipla, líquido cefalorraquidiano, citocinas, lgG síntese intratecal.

Multiple sclerosis (MS) is a disorder of the central nervous system (CNS) characterized by perivascular inflammation and demyelination in the white matter. The etiology and pathogenesis of MS is unknown, although it is a complex phenomenon involving both genetic and environmental aspects. These forces interact to produce individual susceptibility to the disease and influence its course'. Although MS is a disease of the CNS, the peripheral blood and cerebrospinal fluid (CSF) of patients contain activated autoreactive $T$ cells recognizing myelin components such as myelin basic protein (MBP), p roteolipid protein (PLP), myelin associated glycop rotein and myelin oligodendrocyte glycopro te in
$(\mathrm{MOG})^{2}$. Activated T lymphocytes also produce cytokines that modulate the immune response either positively or negatively. Some of these cytokines have proinflammatoryeffects enhancing inflammatory reactions; whereas others have anti-inflammatory properties. The cytokines produced by Th1 cells, such as tumor necrosis factor alpha (TNF $\alpha$ ) and interfe ron gamma (IFN $\gamma$ ), may promote the progress of the disease ${ }^{3,4}$, while those produced by the Th2/Th3 subsets, such as interleukin 10 (IL10) and transforming growth factor beta (TGF $\beta$ ), may limit it ${ }^{5}$. Some authors have also re ported the important contribution of antibodies in the initiation of myelin sheath damage in $\mathrm{MS}^{6}$.

\footnotetext{
${ }^{1}$ Department of Microbiology and Immunology; ${ }^{2}$ Department of Neurology, Medical School, University of Campinas, Campinas SP, Brazil (UNICAMP). Financial support: FAPESP (grant \# 00/07703-7, 01/12827-0); CNPq (grant \# 300375/84-87) and FAEP-UNICAMP.

Received 6 December 2004, received in final form 13 June 2005. Accepted 4 August 2005.

Dra. Leonilda M.B. Santos - Departamento de Microbiologia e Imunologia - Instituto de Biologia / UNICAMP - $13083-970$ Campinas
} SP - Brazil. E-mail: leonilda@unicamp.br 
For diagnosis, magnetic resonance imaging (MRI) has shown great potential as an indicator of disease activity in patients with $\mathrm{MS}^{7}$, with the use of CSF analysis receiving less attention. However, the CSF analysis is still a valuable tool and in association with imaging data provide reliable information about the inflammatory status of a patient.

In the present study, we assessed serum and CSF levels of cytokines, leukocytes count and intrathecal IgG synthesis to evaluate inflammatory activity in a subgroup of untreated MS Brazilian patients during clinical remission.

\section{METHOD}

Patients - Patients were recruited at the hospital of the University of Campinas, located in Campinas, SP, Brazil, during the period of 2002-2004. A total of 58 individuals (42 women and 16 men) were included in the study. At that time, the individuals were divided into three g roups: I. 23 clinically definite MS patients (6 men, 17 women, the mean age was 30) witharelapsing-remitting form of disease (RRMS) according to Poser criteria8; II. 16 patients with other neurologic diseases ( 3 men, 13 women, the mean age was 33): 4 with motor neuron disease, 2 with hereditary sensory-motor neuropathy, 2 with Parkinson's disease, 4 with epilepsy, 2 Alzheimer's disease, 2 with cere brovascular disease; III. 19 individuals (7 men, 12 women, the mean age was 31 years) with backache or headache and who had no evidence of organic neurological disease, studied as a healthy control group. The patients with clinically definite MS who were seen in our MS clinic were studied. MRI and laboratory investigations we re perf o rmed during the initial contact for diagnosis purposes and the determination that the patients were in remission, without treatment. The delay between first attack and first consultation was $4.2 \pm 3.8$ years. The Expanded Disability Status Scale (EDSS) score was determined at lumbar puncture. None of the patients had received corticosteroids or other immunosuppressive drugs during a period of at least 6 months prior to donating CSF and blood for the study. The study was approved by the Medical Ethics Committee of the hospital, and informed consent was obtained.

Samples - All specimens were obtained for the ro utine determination of CSF leukocyte count, IgG synthesis and oligoclonal IgG bands. Paired samples of serum and CSF were stored at $-80^{\circ} \mathrm{C}$ until these exams were performed. The CSF $(10 \mathrm{~mL})$ was taken and cell counting done quickly before sampling.

Laboratory procedures - IgG and albumin in the CSF and serum were measured by nephelometry (BNII; Dade Behring, Marburg, Germany), and Link Indexes (LI) were calculated according to the literature ${ }^{9}$. Oligoclonal IgG bands were identified by isoelectrofocusing ${ }^{10}$.
Antigen, antibody and recombinant cytokines - The IL12, IFN $\gamma$, TNF $\alpha$, and IL10 were quantified using com$m$ e rcial kits from Biosource International, Nivelles, Belgium. All measure was made at the single occasion in order to minimize the intra assay variability. Briefly, 96well microtiter plates were coated with $1-2 \rho \mathrm{g} / \mathrm{mL}$ of captu remonoclonal antibody for each cytokine in $0.1 \mathrm{M}$ $\mathrm{NaHCO}_{3}(\mathrm{pH}=8.5)$ and allowed to incubate ovemight at $4^{\circ} \mathrm{C}$. Following blocking with $3 \%$ dry milk in PBS at room temperature for $2 \mathrm{~h}$, samples and standard recombinant IFN $\gamma$, TNF $\alpha$, IL10 and IL12 were added again and incubated overnight at $4^{\circ} \mathrm{C}$. Then, $0.5-2.0 \rho \mathrm{g} / \mathrm{mL}$ of biotinylated detection monoclonal antibody for human IL12, IFN $\gamma$, TNF $\alpha$ and IL10 were added, followed by the addition of avidin-peroxidase 1/400 (Sigma Chem.- USA) and the peroxidase substrate. A stop solution was used to obtain OD determined at $492 \mathrm{~nm}$.

Imaging - MRIs were performed, using a 2.0 Tesla system (Elscint, Prestige ${ }^{R}$ ). All exams covered the whole brain using $6.0 \mathrm{~mm}$ slice thick and $1.2 \mathrm{~mm}$ inter-slice gap. MRI acquisition parameters for images used for analysis were: T1 sagittal images and T2 axial.

Statistics - The statistical significance of the results was determined using a non-parametric analysis of variance, and a Kruskal-Wallis test and Spearman Rank test. A $p$ value smaller than 0.05 was considered to be significant.

\section{RESULTS}

Twenty three patients with MS were evaluated (Table 1). Brain MRI showed abnormalities with demyelinating lesions in $23(100 \%)$ and presence of gadolinium-enhancing lesions in $5(21 \%)$ of the 23 MS patients. These patients showed CSF hypercytosis and intrathecal IgG synthesis. Twenty-one (91.3\%) MS patients were oligoclonal bands (OCB) positive.

CSF data and patients characteristics of the groups are shown in Table 2. The percentage of patients with hypercytosis was increased in the MS group when compared with the group II (other neurologic diseases; $p=0.004$ ) and group III (healthy controls; $p=0.0001$ ).

Production of TNF $\alpha$ in CSF and serum of pa tients with MS, other neurological disorders, as well as healthy controls - The means for MS patients were $137.3 \pm 119.7$ and $116.0 \pm 115 \mathrm{pg} / \mathrm{ml}$ in serum and CSF, respectively; whereas for the OND group these were $7.6 \pm 24.1$ and $8.6 \pm 28.4 \mathrm{pg} / \mathrm{ml}$ for serum and CSF, respectively; for the healthy controls, these values were $15.3 \pm 19.8$ and $4.3 \pm 8.2 \mathrm{pg} / \mathrm{ml}$. A significant increase $(p<0.001)$ in TNF $\alpha$ was observed in the CSF, and serum of patients with MS. 
Table 1. Clinical and laboratory data of relapsing-remitting multiple sclerosis group.

\begin{tabular}{|c|c|c|c|c|c|c|c|c|c|}
\hline Patient & Age, y & Sex & $\mathrm{DD}$ & N.rel. & EDSS1 & Cells & Alb-I & IgG- I & OB IgG \\
\hline 1 & 44 & $M$ & 1 & 2 & 1 & 8 & 2.6 & 0.65 & + \\
\hline 2 & 32 & $M$ & 3 & 4 & 2.5 & 15 & 5.23 & 0.51 & - \\
\hline 3 & 32 & $\mathrm{~F}$ & 3 & 3 & 1.5 & 20 & 3.64 & 3.35 & + \\
\hline 4 & 37 & $M$ & 3 & 5 & 2 & 2 & 2.82 & 1 & + \\
\hline 5 & 30 & $F$ & 4 & 4 & 3 & 3 & 2.25 & 0.82 & + \\
\hline 6 & 22 & $\mathrm{~F}$ & 4 & 5 & 2 & 16 & 2.4 & 0.98 & + \\
\hline 7 & 10 & $F$ & 8 & 2 & 2 & 14 & 5.84 & 0.84 & + \\
\hline 8 & 25 & $\mathrm{~F}$ & 7 & 4 & 1.5 & 13 & 2.7 & 1.49 & + \\
\hline 9 & 43 & $M$ & 9 & 6 & 2 & 1 & 7.97 & 1.12 & + \\
\hline 10 & 24 & $\mathrm{~F}$ & 2 & 4 & 2 & 15 & 3.25 & 0.76 & + \\
\hline 11 & 46 & $\mathrm{~F}$ & 9 & 3 & 3 & 13 & 6.4 & 1.73 & + \\
\hline 12 & 43 & $\mathrm{~F}$ & 12 & 6 & 2.5 & 3 & 4 & 0.88 & + \\
\hline 13 & 33 & $\mathrm{~F}$ & 5 & 4 & 1.5 & 1 & 5.13 & 0.67 & + \\
\hline 14 & 35 & $\mathrm{~F}$ & 13 & 5 & 2 & 3 & 1.97 & 1.52 & + \\
\hline 15 & 29 & $\mathrm{~F}$ & 11 & 3 & 1 & 16 & 5.9 & 0.81 & + \\
\hline 16 & 43 & $M$ & 8 & 2 & 2 & 1 & 1.66 & 0.59 & - \\
\hline 17 & 25 & $\mathrm{~F}$ & 5 & 4 & 2 & 5 & 3.44 & 0.83 & + \\
\hline 18 & 13 & $M$ & 3 & 9 & 2 & 24 & 4 & 0.74 & + \\
\hline 19 & 21 & $M$ & 7 & 3 & 1 & 5 & 6.17 & 0.6 & + \\
\hline 20 & 37 & $F$ & 1 & 2 & 1.5 & 18 & 5.1 & 2.37 & + \\
\hline 21 & 21 & $F$ & 7 & 6 & 1.5 & 5 & 5.35 & 1.66 & + \\
\hline 22 & 39 & $F$ & 6 & 2 & 1 & 4 & 5.37 & 1.03 & + \\
\hline 23 & 40 & $F$ & 4 & 3 & 2.5 & 5 & 4 & 0.8 & + \\
\hline
\end{tabular}

DD, duration of disease; EDSS1, Expanded Disability Status Scale at the time of the study; Alb-I, albumin index; IgG-I, IgG index; OB IgG, oligoclonal IgG bands; N.rel., number of relapses; y, years.

Table 2. Patients characteristics, number of CSF leukocytes, intrathecal lgG synthesis index and oligoclonal bands.

\begin{tabular}{lcccccc}
\hline Patients & Age, y (mean \pm SD) & Te, y & Sex, M/F & Cells & IgG-index & OB IgG+ \\
\hline MS (23) & $30 \pm 9$ & $5 \pm 3$ & $6 / 17$ & $9.13 \pm 7.05$ & $1.12 \pm 0.66$ & $21 / 23$ \\
ODN (16) & $31 \pm 10$ & $6 \pm 3$ & $3 / 13$ & $4.19 \pm 5.55$ & $0.53 \pm 0.13$ & $1 / 16$ \\
HC (19) & $37 \pm 16$ & - & $6 / 13$ & $1.47 \pm 0.77$ & $0.45 \pm 0.12$ & $0 / 19$ \\
\hline
\end{tabular}

MS, multiple sclerosis; ODN, other neurologic diseases; HC, healthy controls; OB, oligoclonal bands; Te, time of evolution; y, years; SD, standard deviation.

TNFalevels in the CSF exceeded those in the serum for 10/23 patients, suggesting an intrathecal synthesis (Fig 1A). There was a positive correlation between the number of leukocytes in the CSF and the level of TNF $\alpha\left(R^{2}=0.6874, p=0.001\right)$.

Production of IL12p40 in CSF and serum - The means for MS patients were $49.1 \pm 18.3$ and 39.4 $\pm 13.2 \mathrm{pg} / \mathrm{mL}$ for serum and CSF, respectively; whereas for the OND group they were $76.2 \pm 32.2$ and $58.1 \pm 35.1 \mathrm{pg} / \mathrm{mL}$; for the healthy controls these means were $57.4 \pm 18.8$ and $45.4 \pm 15.3 \mathrm{pg} / \mathrm{mL}$. No significant diff e rence ( $p>0.05)$ were observed between the three groups (Fig $1 \mathrm{~B}$ ).
Production of IFN $\gamma$ in CSF and serum patients with MS and, other neurological disorders, as well as healthy controls - The means for MS patients were $500.9 \pm 169.5$ and $359.0 \pm 85.1 \mathrm{pg} / \mathrm{mL}$ in serum and CSF respectively; whereas for the OND group, these were $418.6 \pm 67.0$ and $325.2 \pm 70.5$ $\mathrm{pg} / \mathrm{mL}$; for the healthy controls these mean were $102.6 \pm 102.7$ and $54.1 \pm 39.6 \mathrm{pg} / \mathrm{mL}$. A significant increase $(p<0.001)$ in the IFN $\gamma$ was observed in both CSF and serum of patients with both MS and OND (Fig 1C).

Production of IL-10 in CSF and serum - The means for MS patients were $304.6 \pm 112.0$ and $287.6 \pm$ 


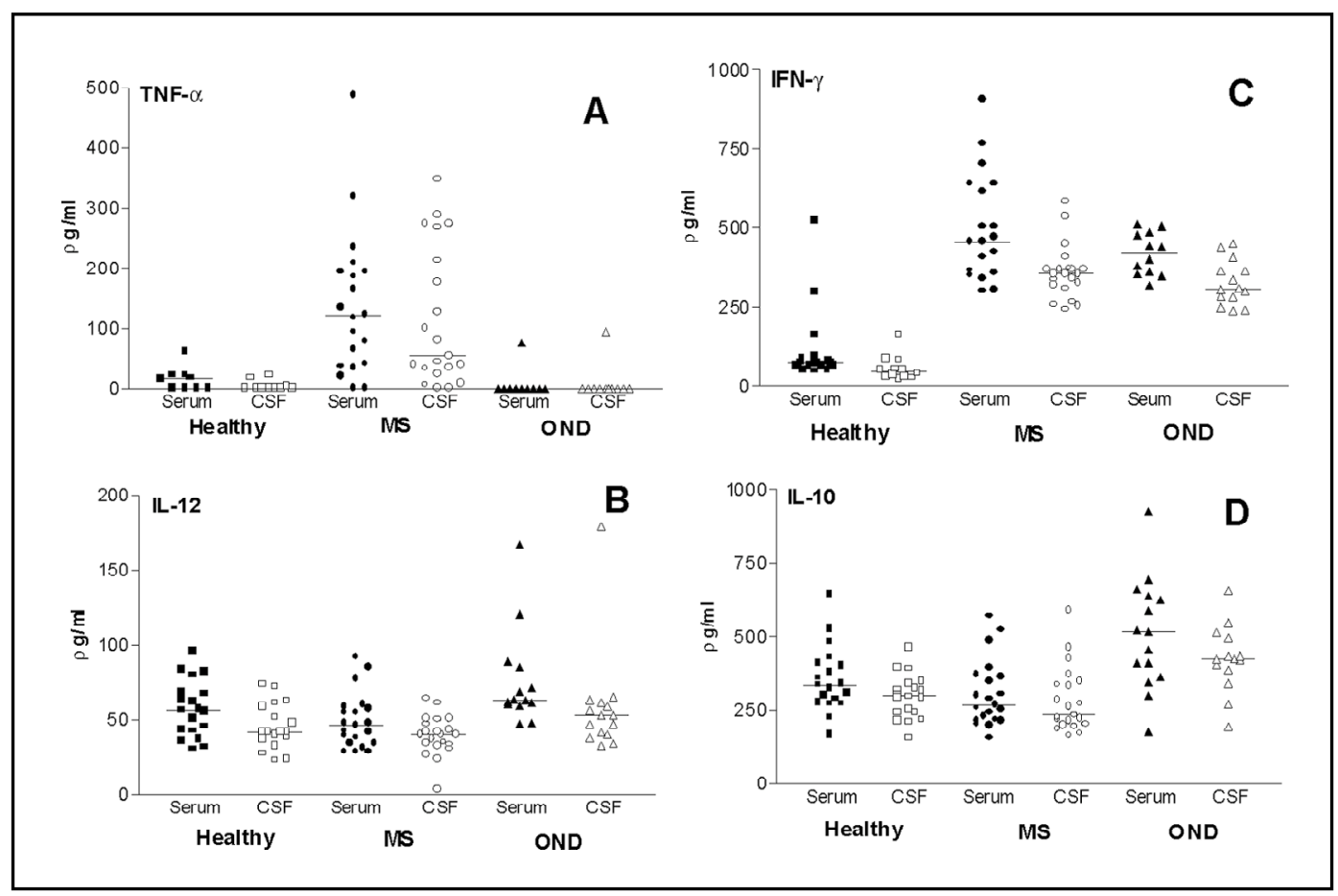

Fig 1. Production of cytokines (TNF $\alpha, I L$ 12, IFN $\gamma$ and IL 10 ) in the CSF and sera from MS patients, OND (oth er neurologic diseases) and healthy controls, detected by ELISA.

$113.7 \mathrm{pg} / \mathrm{mL}$ for serum and CSF, respectively; whereas for the OND group they were $507.6 \pm 187.1$ and $424.3 \pm 113.7 \mathrm{pg} / \mathrm{mL}$ for serum and CSF, respectively; for the healthy controls, these means were $354.6 \pm 111.4$ and $296.2 \pm 74.8 \mathrm{pg} / \mathrm{mL}$. No significant diffe rences were found between the patients with MS and healthy controls ( $p>0.05$ ), whereas the OND group of patients revealed significantly higher levels of IL 10 ( $p=0.006)$ (Fig 1D).

\section{DISCUSSION}

The purpose of this investigation was to evaluate inflammatory activity in MS patients during clinical remission. Our results showed that patients with MS which is identified stable phase of the disease reveal increase in the secretion of pro-inflammatorycytokines in both serum and CSF associated with the increase in the intrathecal synthesis of $\operatorname{lgG}$ and the number of leukocytes in the CSF. This study demonstrated that patients with stable RRMS have an elevated number of leukocytes in the CSF when compared with patients with other non-inflammatorydiseases of CNS and healthy controls. Other studies suggested that the presence of white blood cells in the CSF is a good predictor of the activity of MS, since after two years, patients with a high number of white blood cells in the CSF had more relapses than those in control group ${ }^{11}$.
Parallel to the increase of the number of cells there is also the presence of oligoclonal bands in $91 \%$ of studied MS patients. These results are in agreement with previous Brazilian reports ${ }^{12,13}$. Although the antibody specificity in the oligoclonal bands is still enigmatic, as suggested by reports in the literature, a lack of intrathecal synthesis of oligoclonal lgG bands is related to short lasting and benign course of $\mathrm{MS}^{14}$.

The B-cell proliferation, differentiation and antibody production is coordinated by the helper $T$ cells and the cytokines they produce. Although Th1 and Th2 cells are the major sources of their respective cytokines, many others cells within and outside the immune system also produce these cytokines, contributing to an overall Th1 and Th2 cytokine pattern. It was thus decided to quantify both pro and anti-inflammatory cytokines in the CSF and the serum, independent of their source.

The cytokines produced in the early phase of inflammatory response, such as IL12, contribute to the development of Th1 immune response. Conflicting results regarding IL12 production have, however, been observed in MS. An increase in the production of this cytokine has been observed in progressive $\mathrm{MS}^{15}$ and increased frequencies of IL12 secreting monocytes appear to correlate with 
the presence of active brain lesions detected by $M R I^{16}$. Serum levels of IL12, however, have been found to be similar in MS patients and controls ${ }^{17}$. In the present study, as well, no change in the production of this cytokine was observed in the serum or CSF of MS patients. It seems that, blood monocytes must be stimulated in order to produce detectable amounts of IL12, but since we did not use activated cells, the production of IL12 may have been too low to be detected in the ELISA assay.

The IFN $\gamma$ of MS patients, on the other hand, showed significant increase in the CSF and serum over that of healthy controls, although no difference was observed in relation to the OND group. Initially, interferons were tested as therapeutic agents for MS because of their antiviral properties and it was felt that MS might be due to persistent viral infection. However, a pathogenic role for MS patients who received recombinant IFN $\gamma$ treatment in MS has been reported ${ }^{18}$. Our data support previous ones which demonstrated that IFN $\gamma$ has potent proinflammatory response, including the ability to induce the production of other proinflammatory cytokines ${ }^{19}$. In the animal model, the production of isotypes of IgG, such as IgG2a is induced by the IFN $\gamma$. In our findings, no information is given about the subclass of IgG, which is increased in the CSF of MS patients, but it is possible that the increase in intrathecal IgG production is due to the increase in intrathecal synthesis of IFN $\gamma$.

In addition to the production of IFN $\gamma$, there was a parallel increase of TNF $\alpha$ in the serum and CSF. Approximately $40 \%$ of the MS patients presented levels of TNF $\alpha$ in the CSF equal to or greater than that in the serum, suggesting the intrathecal synthesis of this cytokine. TNF $\alpha$ has been described as a major cytokine in this demyelinating disease, since it has been demonstrated to be myelinotoxic ${ }^{20-23}$. TNF $\alpha$ is also a major inducer of endothelial adhesion molecules and chemokines, hence, the upregulation TNF $\alpha$ may have a major effect on the recruitment of leukocytes to the $\mathrm{CNS}^{24}$. In this study it was possible to show a positive correlation between the number of leukocytes in the CSF and the level of TNF $\alpha$. This property may explain, at least in part, the increased number of inflammation-perpetuating leukocytes observed in the CSF in MS patients. Elevation in CSF concentrations of soluble ICAM-1 and soluble TNF $\alpha$ receptor were demonstrated previously in Brazilian MS patients with acute relapsing form of MS during exacerbation ${ }^{25}$.
As the inflammatory response develops, the cytokine products of Th1 or Th2 lymphocytes pro vide mutually inhibitory functions for the differentiation and effector effect of the reciprocal phenotype. IFN $\gamma$ prevent Th2 cell proliferation, whereas IL10 profoundly inhibits the synthesis of Th1 cytokines ${ }^{26}$. Reports on the IL-10 production showed that patients with high IL-10 production had significantly lower disability scores and lower $\mathrm{T} 2$ lesion load ${ }^{27}$. In the present study, we did not observe significant changes in IL10 levels in MS patients. These data agree with that of studies demonstrating a reduction in IL10 levels in the serum, as well as in the number of IL10-secreting cells in MS patients ${ }^{19,28-30}$, re in fo raing the fact that the proinflammatory response prevails in this group of patients, despite the absence of clinical manifestation.

This study provides evidence of a significant increase in inflammatory activity in patients with stable MS over that in the control groups. These observations suggest that an investigation of the inflammatory parameters in the CSF may provide a valuable tool, which would be useful in the indication of activity of the disease, thus helping understand the damages caused by the inflammatory response.

Acknowledgements - The authors acknowledge the collaboration of Linda Gentry El-Dash in the linguistic revision of the manuscript and of Gislaine C.L. Brito for the technical assistance.

\section{REFERENCES}

1. Steinman L. Multiple sclerosis: a coordinated immunological attack against myelin in the central nervous system. Cell 1996;85:299-302.

2. Ota K, Matsui M, Milford EL, et al. T cell recognition of an immunodominant myelin basic protein epitope in multiple sclerosis. Nature 1999; 346:183-187.

3. Sharief MK, Hentges R Association between tumor necrosis factor $\alpha$ and disease progression in patients with multiple sclerosis. N Engl J Med 1991;325:467-472.

4. Costa PM, Yasuda CL, Scagliusi SM, et al. Pattern of cytokines secretion by peripheral blood cells of patients with multiple sclerosis in Brazil. Mult Scler 2000;6:293-299.

5. Nicoletti F, Di Marco R, Patti F, et al. Blood levels of transforming growth factor beta 1 are elevated in both relapsing-remitting and chronic progressive multiple sclerosis patients and are further augmented by treatment with interferon beta. Clin Exp Immunol 1998;113:96-99.

6. Genain CP, Cannella B, Hauser SL, Raine CS. Identification of autoantibodies associated with myelin damage in multiple sclerosis. Nature Med 1999;5:170-175.

7. Miller DH, Grossman RI, Reingold SC, Mcfarland HF. The role of magnetic resonance techniques in understanding and managing multiple sclerosis. Brain 1998;121:3-24.

8. Poser CM, Paty DW, Scheinberg L, et al. New diagnostic criteria for multiple sclerosis: guidelines for research protocols. Ann Neurol 1983; 13:227-231.

9. Link H, Tibbling G; Principles of albumin and IgG analyses in neurological disorders: III. Evaluation of IgG synthesis within the central nervous system in multiple sclerosis. Scand J Clin Lab Invest 1977; 37:397-401. 
10. Keir G, Luxton RW, Thompson EJ. Isoelectric focusing of cerebrospinal fluid immunoglobulin G: an annotated update. Ann Clin Biochen 1990; 27:436-443.

11. Rudick R, Cookfair D, Simonian N, et al. Cere b rospinal fluid abnormalities in a phase III trial of Avonex (IFN $\beta-1 a$ ) for relapsing multiple sclerosis. J Neuroimmunol 1999;93:8-14.

12. Puccioni-Sohler M, Passeri F, Oliveira C, Brandão CO, Papaiz-Alvarenga R. Multiple sclerosis in Brazil. Analysis of cerebrospinal fluid by standard methods. Arq Neuropsiquiatr 1999;57:927-931.

13. Puccioni-Sohler M, Lavrado FP, Bastos RRG, Brandão CO, PapaizAlva renga R. Esclerose múltipla: correlação clínico laboratorial. A rq Neuropsiquiatr 2001;59:89-91.

14. Verjans E, Theys P, Delmotte P, Carton H. Clinical parameters and intrathecal IgG synthesis as prognostic features for multiple sclerosis. J Neurol 1983;229:155-165.

15. van Boxel-Dezaire AH, Hoff SC, van Oosten BW, et al. Decreased interleukin-10 and increased interleukin-12p40 mRNA are associated with disease activity and characterize diff e rent disease stages in multiple sclerosis. Ann Neurol 1999;45:695-703.

16. Makhloufk K, Weiner HL, Khoury SJ. Increased percentage of IL-12+ monocytes in the blood correlates with the presence of active MRI lesions in MS. J Neuroimmunol 2001;119:145-149.

17. Heesen C, Sieverding F,. Schoser BG, Hadji B, Kunze K. Interleukin 12 is detectable in sera of patients with multiple sclerosis- association with chronic progressive disease course? Eur J Neurol 1999;6:591-596.

18. Panitch HS, Hirsch RL, Schindler J, et al. Treatment of multiple sclerosis with gamma interferon: exacerbations associated with activation of the immune system. Neurology 1987;37:1097-1102.

19. Hohnoki K, Inoue A, Koh CS. Elevated serum levels of IFN gamma, IL4 and TNF $\alpha$ unelevated serum levels of IL10 in patients with demyelinating diseases during the acute stage. J Neuroimmunol 1998; 87:27-32.

20. Buntinx M, Moreels M, Vandenabeele F, et al. Cytokine- induced cell death in human oligodendroglial cell lines: I. Synergistic effects of IFN$\gamma$ and TNF- $\alpha$ on apoptosis. J Neuros Res 2004;76:834-835.

21. Rieckmann $\mathrm{P}, \mathrm{Alb}$ recht $\mathrm{M}$, Kitze B, et al. Cytokine mRNA levels in mononuclear blood cells from patients with multiple sclerosis. Neurology 1994;44:1523-1526.

22. Choffon M, Jillard C, Gauthier G, et al. Tumor necrosis factor production as possible predictor of relapse in patients with multiple sclerosis. Eur Cytokine Netw 1992;433:523-531.

23. Baraczka K, Nékám K, Pozsonyi T, Szuts I, Ormos G. Investigation of cytokine (tumor necrosis factor-alpha, interleukin-6, interleukin-10) concentrations in the cerebrospinal fluid of female patients with multiple sclerosis and systemic lupus erythematosus. Eur J Neurol 2004;11:37-42.

24. Hartung HP, Reiners K, Archelos JJ, et al. Circulating adhesion molecules and tumor necrosis factor in multiple sclerosis: correlation with magnetic resonance imaging. Ann Neurol 1995;38:186-193.

25. Alves-Leon SV, Batista E, Papaiz-Alvarenga R, Quírico-Santos T. Determination of soluble ICAM-1 and TNF $\alpha$ R in the cerebrospinal fluid and serum levels in a population of Brazilian patients with relapsing-remitting multiple sclerosis. Arq Neuropsiquiatr 2001;59:18-22.

26. Mosmann TR, Sad S. The expanding universe of T-cell subsets: Th1, Th2 and more. Immunol Today 1996;138:138-146.

27. Petereit HF, Pukrop R, Fazecas F, et al. Low interleukin- 10 production is associated with higher disability and MRI lesion load in secondary progressive multiple sclerosis. J Neurol Sci 2003;206:209-214.

28. Filion LG, Graziani-Bowering G, Matusevicius D, Freedman MS. Monocyte- derived cytokines in multiple sclerosis. Clin Exp Immunol 2003;131:324-334.

29. Huang W-X, Haung P, Link H, Hillert J. Cytokine analysis in multiple sclerosis by competitive RT PCR: a decreased expression of IL 10 and an increased expression of TNF $\alpha$ in chronic prog ression. Mult Scler 1999;5:342-348.

30. Ozenci V, Kouwenhoven M, Huang Y-M, et al. Multiple sclerosis: levels of interleukin 10-secreting blood mononuclear cells are low in un$\mathrm{t}$ reated patients but augmented using interferon beta $-1 \mathrm{~b}$ treatment. Scand J Immunol, 1999;49:554-561. 